\title{
Are your firm's taxes set in Warsaw? Spatial tax competition in Europe
}

K. Crabbe and H. Vandenbussche

Discussion Paper 2008-50

\section{Département des Sciences Économiques de l'Université catholique de Louvain}




\title{
CORE DISCUSSION PAPER
}

$2008 / 81$

\section{Are your firm's taxes set in Warsaw? Spatial tax competition in Europe}

\section{Karen CRABBE ${ }^{1}$ and Hylke VANDENBUSSCHE ${ }^{2}$}

\author{
December 2008
}

\begin{abstract}
Tax competition within the EU is fiercer than in the rest of the OECD with tax rates falling rapidly. This paper analyzes tax responses of EU-15 countries to corporate tax changes in the EU-10 new member states as a function of their proximity to these new member states. The average corporate tax rate in the new member states has always been considerably lower than the average in the EU-15 countries. Their entry into the EU eliminated capital barriers, allowing firms to locate in one of the new EU-10 with full access to the European Market. Our results indicate that EU-15 countries geographically closer to the new member states respond stronger to corporate tax changes in these new member states. We use a theoretical and a spatial regression framework to test the hypothesis that distance to a low tax region intensifies countries' tax reaction functions.
\end{abstract}

Keywords: spatial tax competition, corporate taxes, fiscal reaction function.

JEL Classification: H25, H77, H39

\footnotetext{
${ }^{1}$ KULeuven and LICOS, B-3000 Leuve, Belgium. E-mail: Karen.crabbe@econ.kuleuven.be

${ }^{2}$ Université catholique de Louvain, CORE, B-1348 Louvain-la-Neuve, Belgium; KULeuven and LICOS, B3000 Leuven, Belgium. E-mail: hylke.vandenbussche@econ.kuleuven.be. This author is also member of ECORE, the newly created association between CORE and ECARES.

This paper presents research results of the Belgian Program on Interuniversity Poles of Attraction initiated by the Belgian State, Prime Minister's Office, Science Policy Programming. The scientific responsibility is assumed by the authors.
} 



\section{Introduction}

Tax competition within the EU is fiercer than in the rest of the OECD with nominal tax rates falling rapidly. This is illustrated in Figure 1. From the mid-nineties onwards, tax rates throughout the OECD countries started to slide. But where this process halted for non-EU OECD countries with average tax rates stabilizing after the year 2004, tax rates in Europe continued to fall. The entry of the new member states $\left(\mathrm{NMS}^{2}\right)$ in 2004 with much lower tax rates than the rest of Europe, did not trigger tax competition, but Figure 1 shows that it seems to have intensified the already existing tax competition in Europe. The average tax rate in the EU15 $5^{3}$ decreased from $38.57 \%$ in 1993 to $28.64 \%$ in 2007.

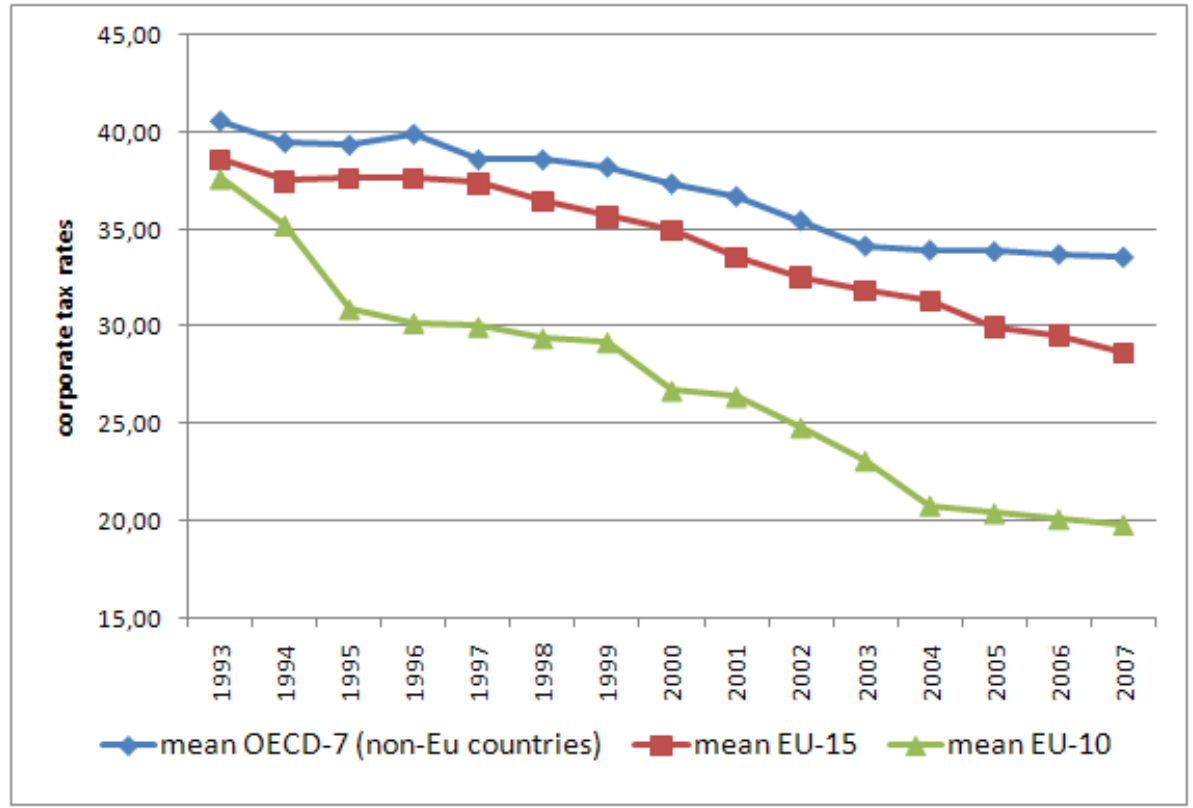

Source: European Commission

Note: OECD-7 non EU-countries= Australia, New Zealand, Canada, Japan, US, Korea, Mexico

Figure 1: Evolution of corporate tax rates in OECD and EU, 1995-2006

\footnotetext{
${ }^{2} \mathrm{NMS}=$ Slovenia, Slovakia, Poland, Czech Republic, Estonia, Latvia, Lithuania, Hungary, Cyprus and Malta

${ }^{3}$ EU-15= Belgium, the Netherlands, Luxembourg, France, Germany, UK, Ireland, Spain, Portugal, Greece, Italy, Finland, Sweden, Denmark and Austria
} 
In fact, casual empiricism suggests that former EU-15 countries geographically close to the NMS such as Germany and Italy experienced tax rates falling faster than those in EU-15 countries further away from the former Central-European countries. This can be seen from Figure 2 where we divide the former EU-15 countries into two separate groups (Figure A in appendix A visualizes which countries have been included in each group). We show average tax rates for "neighboring" countries i.e. countries of the former EU15 that share a land or water border with any of the countries of former Central-Europe (Germany, Austria, Denmark, Finland, Sweden, Italy and Greece). Next, we also show the evolution of the average tax rate of the "non-neighboring" EU countries (Spain, France, UK, The Netherlands, Belgium, Luxembourg and Portugal). It can be noted that the average nominal tax rate of "neighbors" fell more sharply than that of "non-neighbors" where changes were less drastic over time. In this comparison we excluded Ireland which seems to behave very differently from the rest of the EU-15 with tax rates falling even below those of the NMS as early as $1999^{4}$. Despite the fact that we classify "neighbors" and "non-neighbors" somewhat arbitrarily, tax reforms seem to have evolved distinctly different across these two sets of countries.

To understand the different tax behavior of "neighbor" and "non-neighbor" countries, the purpose of this paper is to analyze how "distance to a low tax region" like the NMS affects countries' tax reaction functions. Could it be that countries close to a low tax region are subject to more intense tax competition than others? Using a spatial reaction function approach, we provide evidence confirming the existence of tax competition in Europe. But the evidence suggests that tax reaction functions in Europe are asymmetric. EU-15 "neighbors" of the NMS appear to respond much stronger to taxes set by the new member states than other EU-15 countries. Our findings suggest that German tax rates respond much stronger to taxes set in the NMS than France's tax rates.

For instance, in section 3 of this paper we develop a simple theoretical model that offers an explanation for why Germany rather than France is more subject to tax competition from the NMS. Our analysis shows that "geography" matters. In our model, countries have a

\footnotetext{
${ }^{4}$ We will treat Ireland as an outlier which will initially be dropped from the analysis but will be included in the robustness section.
} 
Figure 2: Tax Rate of the neighbors versus non-neighbors of the new member states

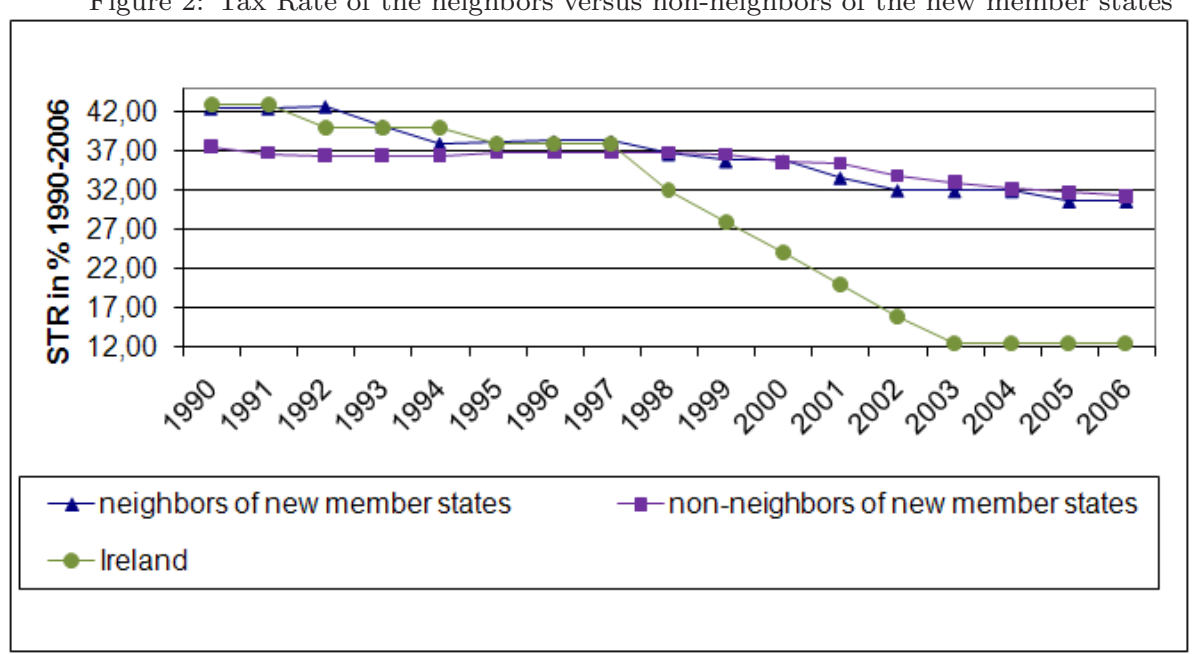

Neighbors: Germany, Austria, Denmark, Finland, Sweden, Italy and Greece; Non-neighbors: Spain, France, UK, Netherlands, Belgium, Luxembourg and Portugal

The STR is not weighed. Source: Vandenbussche and Crabbé (2006), extra data included for 2005 and 2006.

fixed geographical position but footloose firms can move freely between them. It will become clear that countries closer to a low tax region are more subject to tax competition and will set a lower tax rate than more remote countries. An intuitive way to think about this is to make the comparison with the product space. In a Hotelling type of model with transport costs it is a well known result that when firms locate geographically further apart, pricecompetition is less fierce and firms are less affected by price cuts of rival firms. Similarly, this paper finds that tax premia are higher the further away a country is from a low tax region. Or put differently, we find asymmetric tax response of countries in the EU-15 to the low taxes in the NMS. Germany, while strongly affected by the tax rates set in say Poland, does not seem to be significantly affected by the tax rates set by France. Hence, tax competition in Germany seems predominantly to come from countries located to its right and not to its left.

We are not the first to look at spatial reaction issues. Earlier studies have looked at tax rates interdependence in the EU-15 or in the OECD such as Devereux et al. (2008), Altshuler and Goodspeed (2002), Redoano (2003), Ruiz and Gerard (2007) and Davies and Voget 
(2008). The results we obtain in this paper shed additional light on earlier findings. We confirm the weak tax interdependency amongst the countries of 'old Europe' reported earlier. But in contrast to earlier studies, we include the new member states and find evidence of asymmetric fiscal responses between European countries which seems to be determined by the geographical distance to the low tax countries in the new member states. In our analysis, we consider Ireland to be an outlier in the EU-14 in terms of tax competition in view of the fact that its tax rate shows a very different pattern relative to other EU countries as shown in Figure 2.

The rest of the paper is as follows. In section 2 we discuss related literature and previous findings. Section 3 develops a simple theoretical model for the purpose of guiding the empirical analysis. Section 4 discusses the empirical methodology and the data. Section 5 reports the results and the final section concludes.

\section{Related Literature on Fiscal Reaction Functions}

Devereux et al. $(2008)^{5}$ analyze strategic tax competition in 21 OECD countries in the period 1982-1999. They find that countries strategically compete over the statutory tax rate and effective tax rate $^{6}$ and that countries with relatively high effective tax rates react more strongly to tax rates in other countries. Altshuler and Goodspeed (2002) are the first to study tax competition in EU-15 countries. Their findings suggest that EU-15 countries react to the corporate $\operatorname{tax}^{7}$ of geographically close countries, but do not react to the personal income tax of geographic neighbors. They find that ever since the US tax reform of 1986, European countries compete to a lesser extent with the US on corporate tax rates. Redoano (2003) also studies tax reaction functions between EU countries. Using statutory tax rates for $13 \mathrm{EU}$ countries during the period 1980-1995, she finds that tax competition mainly occurs between countries that are geographically close. Ruiz and Gerard (2007) provide empirical evidence of weak tax reactions between neighboring EU-15 countries for statutory

\footnotetext{
${ }^{5}$ See Brueckner (2003) and Allers and Elhorst (2005) for an overview of the fiscal reaction literature.

${ }^{6}$ effective tax rate calculated using the forward looking method, see Devereux et al. (2002).

${ }^{7}$ Altshuler and Goodspeed (2002) use the corporate tax revenues as a percentage of GDP as corporate tax measure and the personal income revenue as a percentage of GDP as personal income tax measure.
} 
and effective tax rates during the period 1989-2001. Finally, Davies and Voget (2008) investigate whether the expansion of the European Union intensified tax competition since EU-countries have a larger market potential (domestic market combined with access to foreign markets). There results indicate that non-EU members respond equally to other countries regardless of membership, while EU members respond more to other EU-members tax rates. The authors use the average effective tax rate as a measure of taxes and do not distinguish among EU-members.

This paper is the first to include the EU's new member states. We find empirical evidence of asymmetric fiscal responses between EU-14 countries determined mainly by the geographical distance of each country to the low tax countries in the new member states.

\section{The model}

In this section we develop a simple theoretical model that can explain some of the stylized facts outlined in the introduction. The set up is similar to Haufler and Wooton (1999) but additionally introduces spatial 'distance' into the model. The assumptions are carefully chosen in order to keep the model as tractable as possible. We assume that a foreign, say U.S., multinational (MNE) intends to invest in Europe. It has the choice of locating in one of two countries: country A (EU-15) or country B (NMS) ${ }^{8}$. Where we assume country A to be the larger market of the two. This assumption arguably reflects the current situation in the enlarged EU market. If the MNE decides to set up in one country, it will face a transport cost $(c)$ when exporting to the other country, while there are no transport costs to distribute the good within a country. Marginal production costs ${ }^{9}$ and fixed costs are assumed to be equal in both countries and are dropped from the analysis. The staging of events is as follows:

1. Countries $\mathrm{A}$ and $\mathrm{B}$ set their tax rates $\left(t_{A}, t_{B}\right)$ simultaneously in order to maximize their welfare.

\footnotetext{
${ }^{8}$ For simplicity we reduce enlarged Europe into two separate countries, but they can also be thought of as two individual countries each belonging to one of the two countries EU-15 or NMS.

${ }^{9}$ It is true that wage costs in Central Europe are lower but studies have shown that productivity is also lower which to a large extent offsets their wage advantage. Therefore for simplicity we assume that these costs cancel out and that marginal production costs are equal.
} 
2. The multinational chooses to locate in $\mathrm{A}$ or $\mathrm{B}$, taking into account the tax rates and transportation cost.

3. The multinational decides on local output and exports to the other country to maximize after-tax profits.

The model can be solved through backwards induction. In stage 3 , the multinational decides on output and exports to maximize its after-tax profits. We assume the inverse demand functions of country A and B to be respectively, $P_{A}=\left(M-Q_{A}\right)$ and $P_{B}=\left(m-Q_{B}\right)$, where the market size $M$ is substantially larger than the market $m$. The after-tax profit $\left(\pi_{A}\right)$ of the multinational when choosing to locate in $\mathrm{A}$ is:

$$
\pi_{A}=\left(\left(M-Q_{A}\right) Q_{A}+\left(m-Q_{A B}\right) Q_{A B}-c x Q_{A B}\right)\left(1-t_{A}\right)
$$

The first term represents the sales in country A, the second term is the sales in country B and the third term is the transport cost $(c)$ of shipping the exported quantity $\left(Q_{A B}\right)$ over a distance $x$ which is the distance between country A and $\mathrm{B}$. And $t_{A}$ is the corporate tax rate in country A. The expression for the after-tax profit of the multinational when locating in $\mathrm{B}$ is:

$$
\pi_{B}=\left[\left(m-Q_{B}\right) Q_{B}+\left(M-Q_{B A}\right) Q_{B A}-c x Q_{B A}\right]\left(1-t_{B}\right)
$$

Maximizing these after-tax profits and using the equilibrium outputs ${ }^{10}$ in (1) and (2), leads us to the equilibrium after-tax profits of the multinational in country A or B, respectively:

$$
\begin{aligned}
\pi_{A}^{*} & =\frac{M^{2}+(m-c x)^{2}}{4}\left(1-t_{A}\right) \\
\pi_{B}^{*} & =\frac{m^{2}+(M-c x)^{2}}{4}\left(1-t_{B}\right)
\end{aligned}
$$

We start by deriving the 'indifference tax rate'. The multinational will be indifferent between locating in country A or B when its after-tax profits in country A equals its after-tax profit in country B. This applies when

$$
\pi_{A}^{*}=\pi_{B}^{*} \Leftrightarrow t_{A}^{\text {Indiff }}=\frac{2 c x(M-m)+t_{B}\left(m^{2}+(M-c x)^{2}\right)}{M^{2}+(m-c x)^{2}}
$$

\footnotetext{
${ }^{10}$ The equilibrium outputs are derived in Appendix B.1, in order for the outputs to be positive, the following conditions must be true: $\mathrm{M}>\mathrm{cx}$ and $\mathrm{m}>\mathrm{cx}$.
} 
Or written differently for country B this yields

$$
t_{B}^{\text {Indiff }}=\frac{2 c x(m-M)+t_{A}\left(M^{2}+(m-c x)^{2}\right)}{\left(m^{2}+(M-c x)^{2}\right)}
$$

The expression above already indicates that the indifference tax reaction function of country $\mathrm{A}$ is a function of the transport cost $c$ between $\mathrm{A}$ and $\mathrm{B}$, the distance $x$ between the two countries, the tax rate $t_{B}$ of the other country B and the market size of both countries $M$ and $m$. This indifference reaction function has some features that can explain the observed stylized facts. For instance, it can be noted that the tax rates of country A and B are strategic complements since $t_{B}$ enters the indifference reaction function of $t_{A}$ with a positive sign and vice versa.

Proposition 1. Tax rates between countries are strategic complements.

This implies that a decrease (rise) in the tax rate of country B will be met by a decrease (rise) in the tax rate of country A. This seems to confirm the facts presented in Figure 2 where all European tax rates are more or less falling together. The empirical part of the paper will use this reaction function to analyze to what extent tax rates of the EU-15 countries are sensitive to tax changes in the NMS.

In stage 1 of the tax game, we define the welfare objective function of each country as the sum of consumer surplus (CS) and tax income (tax on profits before tax) if the multinational locates in that country. To simplify things, we assume that the U.S. multinational does not reinvest its equilibrium profits in Europe, but shifts all its profits back to the US which is why its profits are not included in a country's welfare function. Therefore each country's welfare in the presence of the MNE can be represented as follows:

$$
W_{i}=C S_{i}+t_{i} \frac{\pi_{i}^{*}}{1-t_{i}}
$$

Depending on whether the MNE locates in country A or in country B, the welfare for A will be different. When the multinational locates in country A (option 1), the welfare of country $A$ is

$$
W_{A 1}=\frac{M^{2}}{8}+t_{A} \frac{M^{2}+(m-c x)^{2}}{4}
$$


If the multinational decides to locate in country B (option 2) and exports to country A, the welfare of country A is

$$
W_{A 2}=\frac{M^{2}-6 c x M+5 c^{2} x^{2}}{8}
$$

In this case, country B acts as an FDI export platform ${ }^{11}$.

Country A will be indifferent between being the host of the MNE versus importing the good from country $\mathrm{B}$, when the welfare in both options is equal: $W_{A 1}=W_{A 2}$. This equality determines the minimal tax rate or the maximum subsidy $\left(\tilde{t}_{A}\right)$ that country $\mathrm{A}$ is willing to offer in order to attract the firm.

$$
\begin{aligned}
W_{A 1} & =W_{A 2} \\
\frac{M^{2}}{8}+t_{A} \frac{M^{2}+(m-c x)^{2}}{4} & =\frac{M^{2}-6 c x M+5 c^{2} x^{2}}{8} \\
\tilde{t_{A}} & =\frac{5 c^{2} x^{2}-6 c x M}{2\left(M^{2}+(m-c x)^{2}\right)}
\end{aligned}
$$

Similarly for B, the minimal tax rate or maximum subsidy $\left(\tilde{t_{B}}\right)$ that country B is willing to offer in order to attract the firm is

$$
\begin{aligned}
W_{B 1} & =W_{B 2} \\
\frac{m^{2}}{8}+t_{B} \frac{m^{2}+(M-c x)^{2}}{4} & =\frac{(m-c x)^{2}-4 c x(m-c x)}{8} \\
\tilde{t_{B}} & =\frac{5 c^{2} x^{2}-6 c x m}{2\left(m^{2}+(M-c x)^{2}\right)}
\end{aligned}
$$

Since by assumption $M>c x$ and $m>c x$ ), we know that $\tilde{t_{A}}$ and $\tilde{t_{B}}$ are negative. Hence, they are both willing to offer a subsidy to the MNE in order to attract the MNE. This implies that having a MNE always raises welfare in both countries.

Using (11) in (5), we can derive the maximum tax rate that country A can charge while keeping the firm indifferent between locations and given country B's best offer.

$$
t_{A}^{*}=\frac{4 c x M+5 c^{2} x^{2}-10 c x m}{2\left(M^{2}+(m-c x)^{2}\right)}
$$

Since the market size in country $\mathrm{A}$ is larger than in $\mathrm{B}(M>m), t_{A}^{*}$ is positive suggesting that A can charge a tax rate and still keep the multinational indifferent between locations.

\footnotetext{
${ }^{11}$ A FDI export platform means that FDI is attracted to country B that is located near other valuable markets such as country A, because country B makes a good platform for reaching country A and is usually cheaper in location (taxes, labor costs, etc) (Bloningen et al. (2007); Ekholm et al. (2007)).
} 
A similar calculation for country B gives us

$$
t_{B}^{*}=\frac{4 c x m+5 c^{2} x^{2}-10 c x M}{2\left(m^{2}+(M-c x)^{2}\right)}
$$

which is negative or in other words country B needs to subsidize the MNE to keep the MNE indifferent between locations. Comparing (12) and (13), we can show that the larger market of country A implies that it can set a (positive) tax premium compared to country B (see appendix B.3 for a proof). This result confirms Haufler and Wooton (1999) and Baldwin and Krugman (2004) who find that larger countries can set a higher tax rate.

Proposition 2. A larger country sets a higher equilibrium tax than a smaller country.

This confirms the stylized facts in Figure 1 where we noted that the tax rate of EU-15 is higher than the tax rate of the $\mathrm{NMS}^{12}$. But most importantly for our purposes, a comparative static of the tax rate of country A with respect to the distance between country A and country B, leaving everything else constant, shows that the tax premium of country A increases with the distance between both countries $\left(\frac{\partial t_{A}^{*}}{\partial x}>0\right.$, see appendix B.3). Or put differently, the further country $\mathrm{A}$ is to the smaller country B (the smaller $x$ ), the higher the tax premium country A can set. In terms of individual countries this implies that a country belonging to the older EU members (EU-15) that lies further away from the NMS can set a higher tax rate than another EU-15 country closer to a low tax NMS country. This is the result we aim to test and that will guide our empirical analysis in the next section.

Proposition 3. The geographical distance between a country of the EU-15 and the new member states (NMS), determines the tax premium, with a lower tax premium for countries closer to the low tax area.

\section{Methodology and Data}

The theoretical framework above has shown that distance matters and that tax premia tend to fall for countries closely located to a low tax region. Based on the theory, we conjecture

\footnotetext{
${ }^{12}$ We only consider the domestic market size, while Davies and Voget (2008) take into account the market potential of a country which is the domestic market combined with the access to export to other markets.
} 
that EU countries closer to the NMS will exert a stronger tax reaction to tax changes in the NMS than EU countries further away from the NMS. In this section, we empirically test this hypothesis using spatial regression analysis to uncover the existence of fiscal reaction functions between groups of countries. This method links the tax rate of one country to the tax rate of other countries taking into account the distance between these countries (Besley and Case (1995); Bordignon et al. (2002); Brueckner (2003)). We start by testing the reaction of the EU-14 countries (Ireland excluded from the EU-15 for reasons explained in the introduction) on the tax rates of the new member states (NMS) during the period 1993-2006. Based on the literature we use the following specification to test for the existence of tax interdependence:

$$
\begin{aligned}
T A X_{i_{E U 14}, t}= & \beta_{1}\left(\sum_{i \neq j} w_{i j} T A X_{j_{N M S}, t}\right)++\beta_{2} X_{i E U 14, t} \\
& +\alpha_{i E U 14}+\varepsilon_{i E U 14, t}
\end{aligned}
$$

The dependent variable $T A X_{i E U 14, t}$ represents the vector of individual corporate tax rates of all EU-14 countries (Ireland excluded) which are assumed to be a function of the right hand side variables in (14) including corporate tax rates of the new member states $\left(T A X_{j N M S, t}\right)$ where each of the latter is weighted by its distance to the individual EU-14 country $\left(w_{i j}\right)$. We further include a set of additional country control variables $X_{i E U 14, t}$ and country-specific effects $\alpha_{i}$. The country control variables $X_{i E U 14, t}$ that we include are: the personal income tax rates, mainly to allow for shifts in the tax burden from firms to workers; the GDP per capita, as a control for the demand for public services Altshuler and Goodspeed (2002) and the population younger than 14 and older than 65 years, to control for the active population and the market size. Of all the right hand side variables, the coefficient $\beta_{1}$ on the weighted corporate tax rate of the NMS is our main variable of interest. The initial weights are the inverse distance between the capital cities of any EU-14 country and the countries of the $\mathrm{NMS}^{13}$. This implies that a NMS closer to a EU-14 country will have a larger weight in the analysis. Significance of the coefficient $\beta_{1}$ implies that the tax rates of

\footnotetext{
${ }^{13}$ Distance data is collected from the CEP II database based on the 'great circle formula' which uses latitudes and longitudes of cities and incorporates the internal distance of the country Head and Mayer (2002).
} 
EU-14 countries respond to a change in the tax rates of NMS. In the robustness checks, we will also experiment with alternative weights Bloningen et al. (2005).

A simple OLS estimation of the specification in (14) encounters some methodological problems. For one, the weighted tax rates of the NMS $\left(\sum w_{i j} T A X_{j N M S, t}\right)$ in (14) can be endogenous. While tax rates of the NMS may affect tax rates in EU-14 countries, the inverse may also hold. To address this problem, we apply an IV-approach (2SLS) often used in the literature (Brueckner (2003); Altshuler and Goodspeed (2002); Redoano (2003); Heyndels and Vuchelen (1998); Brett and Pinkse (2000); Carlsen et al. (2005), Egger et al. (2005), etc.). In the first stage of this IV-approach, we regress the endogenous $\left(\sum w_{i j} T A X_{j N M S, t}\right)$ variable on a set of instruments and the exogenous control variables as follows.

$$
\text { First stage : } \sum_{i \neq j} w_{i j} T A X_{j_{N M S}, t}=\alpha_{1} \sum_{i \neq j} w_{i j} X_{j_{N M S}, t}+\alpha_{2} X_{i_{E U 14}, t}+\alpha_{j}+\rho_{j t}
$$

The set of instruments $\left(X_{j N M S, t}\right)$ we choose are similar to the literature and include the proportion of population younger than 14 years, the proportion of population older than 65 years and GDP per capita. The instruments are weighted with the same weights as the tax rates of the NMS. The vector $X_{i E U 14, t}$ is the same set of control variables as in equation (14) and $\alpha_{j}$ controls for country-specific effects. In the second stage, equation (14) is estimated using the fitted values of $\sum w_{i j} T A X_{j N M S, t}$ from equation (15). In this stage, we need to control for autocorrelation in the tax rates of the EU-14 countries because of persistence in the tax rates over time. Including a lagged dependent variable in a fixed effects model would result in multicollinearity since fixed effects are time invariant Woolridge (2003). Therefore, we opt for a country fixed effects model where we introduce dynamics by allowing for a first order autocorrelation process $(\operatorname{AR}(1))$ in the error term ${ }^{14}$.

\section{Results}

The results of the second stage estimations are reported in Table 1. The results of the first stage IV regression are reported in Table B in appendix D. In all columns, we instrument ${ }^{15}$

\footnotetext{
${ }^{14}$ This is the 'Xtregar' command in the statistical program Stata which takes into account an AR(1) disturbance term: $e_{i t}=\rho * e_{i, t-1}+z_{i t}$ with $z_{i t}$ independent and identically distributed.

${ }^{15}$ The instruments for $\sum w_{i j} T A X_{j N M S, t}$ are: $w_{i j}$ (proportion of the population older than 14 years $j t$ ), $w_{i j}$ (proportion of the population younger than 65 years $\left.j t\right), w_{i j}\left(\mathrm{GDP}\right.$ per capita $\left.{ }_{j t}\right)$.
} 
the weighted tax rates in the new member states $\left(\sum w_{i j} T A X_{j N M S, t}\right)$ for reasons outlined in the section above.

In column (1) we test for an EU-14 wide fiscal reaction function with respect to the tax rates in the new member states (NMS). The results confirm the theoretical proposition 1 and are suggestive of an EU-wide positive fiscal reaction function of the EU-14 countries with respect to the new member states (NMS). In columns (2) and (3) of Table 1, we split up the sample into 'neighbors' and 'non-neighbors' of the NMS. In column (2) of Table 1, we only consider the tax rates of the 'neighboring' EU-14 countries as a dependent variable. We find the coefficient of the NMS tax rates to be strong and significant at the $1 \%$ levelThis indicates that a decrease in the tax rates of the NMS by $10 \%$, will lead to a decrease of $16 \%$ in the tax rates of the 'neighboring countries'. This suggests that Germany's tax rate is affected by Poland's tax rate. We also note that the coefficient on the non-neighbors' tax rate is not significant. This seems to suggest that the tax rate of Germany is not affected by the tax rate in Poland. In column (3) where we only consider the tax rates of 'non-neighbors' of NMS as dependent variables, the coefficient of the tax rates of the NMS, while positive in sign, is not significant. This suggests that low tax rates in the NMS affect taxes in their neighboring countries, but not in other EU countries that are more distant. But we fail to find a significant reaction of the tax rates set by non-neighbors. This suggests that the tax rate of a non-neighbor country like France does not seem to be affected by the tax rate of a neighbor country like Germany. It becomes clear that EU-14 countries geographically closer to the NMS (column (2)) react stronger to changes in the tax rates of NMS than EU-14 countries further away from the NMS (column (3)), which seems to confirm that geography matters for the extent of tax competition as suggested in proposition 3.

Thus far, we have excluded Ireland from the analysis as Ireland appears to be an outlier and for which we do not really have a good explanation. We could already see form Figure 2 that tax rates in Ireland dropped much faster than in any other EU-14 country. Ever since 1999, the Irish tax rate has dropped below the level of NMS countries which is very atypical compared to the rest of EU-14 that all have a positive tax premium compared to the NMS. Ireland itself is a low tax region compared to the other EU-14 which is why, as an experiment, in column (4) of Table 1 we include Ireland in the group of NMS countries. 
When including Ireland in the group of NMS, the coefficient on the fiscal reaction function is much smaller and not significant suggesting that the tax regime in Ireland does not affect continental countries.

Table 2 reports some robustness checks. In column (1), we use a different set of instruments for $\sum w_{i j} T A X_{j N M S, t}$. Since it can be argued that tax setting is part of the institutional framework of a country, we instrument $\sum w_{i j} T A X_{j N M S, t}$ by a set of institutional variables $^{16}$. The estimates in column (1) show that the fiscal reaction function is still positive and significant. This indicates that the result is robust to an alternative set of instruments. Columns (2), (3) and (4) in Table 2 are robustness checks using alternative weights $w_{i j}$ for the NMS' tax rates. In column (2) we weigh the tax rates of the NMS using a dummy equal to 1 if the NMS have a common land or water border with the EU-14 country and 0 otherwise. The result is positive and significant, indicating that the tax rates of the EU-14 countries adjacent to the NMS are significantly influenced by the tax rates of the NMS. This confirms our earlier findings where we used a continuous distance measure between countries as weights.

In column (3) the tax rates of the NMS are weighted using export shares. These export shares are defined as the exports from the EU-14 country $(i)$ to a country of the NMS $(j)$ as a share in the total export of the EU-14 country $(i)$. The fiscal reaction function of export partners is not significant. In column (4) we construct a weight for similar economic characteristics ${ }^{17}$. A higher weight $w_{i j}$ indicates that EU-14 country $i$ has a similar economic development than country $j$ of the NMS. In other words, we analyze whether countries such as Spain and Portugal react stronger to tax rates of the NMS than other EU-14 countries because their economic development is more similar to the NMS. The result shows that EU14 countries with similar economic characteristics as the NMS do not react to tax changes in the NMS. Overall, the results of Table 2 reflect the lower importance of trading relationships and economic similarity. Geographical distance of an EU country to the NMS seems to be

\footnotetext{
${ }^{16} w_{j t}$ is replaced by indices of price liberalization, privatization and enterprise reforms. These institutional variables are collected from the EBRD reports. The first stage regression with these set of instruments is reported in Table $\mathrm{C}$ in Appendix D, Table C.

${ }^{17}$ In column (4): $\mathrm{w}_{i j}=\frac{1}{\sum\left(G D P_{i}-G D P_{j}\right.}$
} 
Table 1: Estimation Results

\begin{tabular}{|c|c|c|c|c|}
\hline \multirow[t]{2}{*}{ dep var. $=\operatorname{tax}_{i}$} & (1) & $(2)$ & $(3)$ & $(4)$ \\
\hline & EU-14 & only neighbors & only non-neighbors & EU-14, Ireland \\
\hline \multirow{2}{*}{$\mathrm{WTax}_{N M S, t}$} & $0.57^{*}$ & $1.68^{* * *}$ & 0.45 & -0.001 \\
\hline & $(0.32)$ & $(0.65)$ & $(0.32)$ & $(0.001)$ \\
\hline WTax $_{\text {non-neighbors }, t}$ & - & $\begin{array}{r}-0.98 \\
(0.89)\end{array}$ & - & - \\
\hline $\mathrm{WTax}_{\text {neighbors }, t}$ & - & - & $\begin{array}{c}0.24 \\
(1.9)\end{array}$ & - \\
\hline \multirow[t]{2}{*}{ Income $\operatorname{tax}_{t-1}$} & 0.2 & 0.64 & 0.38 & 0.3 \\
\hline & $(0.21)$ & $(0.54)$ & $(0.24)$ & $(0.26)$ \\
\hline \multirow[t]{2}{*}{ population $>14$} & 0.63 & -1.29 & 0.16 & $3.21^{*}$ \\
\hline & $(1.95)$ & $(2.64)$ & $(2.34)$ & $(1.7)$ \\
\hline \multirow[t]{2}{*}{ population $<65$} & -2.1 & $-5.96^{* * *}$ & 0.33 & -1.7 \\
\hline & $(1.38)$ & $(2.12)$ & $(1.51)$ & $(1.42)$ \\
\hline \multirow[t]{2}{*}{ gdp per capita } & -0.0001 & $0.002^{*}$ & -0.0001 & -0.0002 \\
\hline & $(0.0002)$ & $(0.001)$ & $(0.0002)$ & $(0.0002)$ \\
\hline \multirow[t]{2}{*}{ constant } & $33.48^{* * *}$ & 59.98 & 13.22 & 3.88 \\
\hline & $(10.33)$ & $(24.48)$ & $(21.55)$ & $(9.44)$ \\
\hline Observations & 126 & 56 & 63 & 126 \\
\hline R-squared (within) & 0.12 & 0.33 & 0.34 & 0.09 \\
\hline
\end{tabular}

Standard errors are in parentheses. The instruments used for $\operatorname{TTax}_{N M S, t}$ : the proportion of the population older than 14 years, proportion of the population younger than 65 years, GDP per capita and the lagged income tax rate of the NMS. These instruments are also weighted with the distance. note:***,** and $*$ denote significance level of estimates at respectively 1,5 and 10 percent levels.

much more important in determining a country's tax reaction function. Conversely, Davies and Voget (2008) use a broader weight based on market potential and they do find EUcountries to respond on tax rates of other EU-members with more market potential. From our analysis it can be noted that EU-14 countries close to the low tax countries of the NMS face much stronger tax competition than other EU-14 countries. 
Table 2: Robustness Checks

\begin{tabular}{lrrrr}
\hline dep var.=tax $E U-14 i$ & $(1)$ & $(2)$ & $(3)$ & $(4)$ \\
& & W=border dummy & W=exportshare & W= gdp per capita \\
\hline WTax $N M S, t$ & $0.25^{* *}$ & $0.45^{*}$ & 0.05 & 0.34 \\
& $(0.13)$ & $(0.27)$ & $(0.17)$ & $(0.24)$ \\
Income $\operatorname{tax}_{i, t-1}$ & 0.24 & 0.19 & 0.16 & -0.004 \\
& $(0.2)$ & $(0.24)$ & $(0.21)$ & $(0.24)$ \\
$14<$ population $>65$ & $4.41^{* * *}$ & - & - & 0.81 \\
& $(1.26)$ & & & $(1.94)$ \\
population $>14$ & - & 0.18 & -1.78 \\
& & $(1.92)$ & $(1.61)$ & $(1.27)$ \\
population $<65$ & $-3.39^{* * *}$ & -1.82 & 0.0 \\
& $(1.47)$ & -0.0001 & $(1.31)$ & $(0.0002)$ \\
gdp per capita & -0.0002 & $(0.0002)$ & $(0.0002)$ & -0.004 \\
& $(0.0002)$ & 0.19 & 0.16 & $(0.24)$ \\
income tax & 0.24 & $(0.24)$ & $(0.21)$ & $33.95^{* * *}$ \\
constant & $(0.2)$ & $67.9 * * *$ & $14.34^{*}$ & $(8.64)$ \\
\hline Observations & $-246.92^{* * *}$ & $(13.85)$ & $(8.11)$ & 140 \\
R-squared (within) & $(24.54)$ & 114 & 140 & 0.1 \\
\hline \hline
\end{tabular}

Standard errors are in parentheses. In column $(1), \operatorname{WTax}_{N M S, t}$ is instrumented with institutional variables such as an index of trade liberalization, privatization and enterprise reforms. In columns (2), (3) and (4) the following instruments are used: the proportion of the population older than 14 years, proportion of the population younger than 65 years, GDP per capita and the lagged income tax rate of the NMS. These instruments are also weighted with the distance. note:***,** and ${ }^{*}$ denote significance level of estimates at respectively 1,5 and 10 percent levels. 


\section{Conclusion}

In this paper, we have analyzed the spatial dimension of corporate tax competition in Europe. The purpose was to investigate whether former EU-15 countries closer to the EU new member states (NMS) experience more tax competition than those EU-countries further away from the new member states. A simple theoretical model with footloose firms and transport costs demonstrate that a country's tax reaction function positively depends on its proximity to low tax countries i.e. the further away from a low tax region, the higher the tax premium a country can set. Using a spatial reaction function approach, we provide empirical evidence of the fiscal reaction functions between groups of countries in Europe. Our analysis suggests that 'neighboring countries' of the new member states (Germany, Italy, Sweden, Denmark, Austria and Greece) reacted much stronger to changes in the tax rates of the new member states than 'non-neighboring countries' (France, Belgium, Netherlands, UK, Spain and Portugal).

Surprisingly, the analysis suggests an asymmetric response whereby the EU-14 (Ireland is excluded) 'neighbors' respond to taxes set by the new member states, i.e. German tax rates respond to those set in Poland. But we fail to find evidence of a fiscal reaction function of the 'neighbors' to tax rates set by the 'non-neighbors', i.e. Germany's taxes do not respond to France's tax rates. In other words, tax competition in EU-countries seems predominantly to come from countries located to the East not the West. Also, we do not find a fiscal reaction function for 'non-neighbors'. Their tax rates do not appear to be affected by the NMS or the 'neighbors' of the NMS. These asymmetric results may explain why Ruiz and Gerard (2007) find only weak evidence of tax mimicking behavior amongst EU-15 countries. While our study leaves many issues unaddressed, if anything it suggests the existence of asymmetric tax responses between EU countries.

\section{Acknowledgements}

We thank "steunpunt fiscaliteit \& begroting" funded by the Flemish government for funding this research. A special thanks goes to Pascalis Raimondos-Møller, Thomas Ulen, Ben Lockwood, Andreas Haufler, Dirk Heremans, Jozef Konings, Wim Moesen, Christophe Croux and Isabelle Thomas for useful feedback. 


\section{Appendices}

A. Map of EU-25

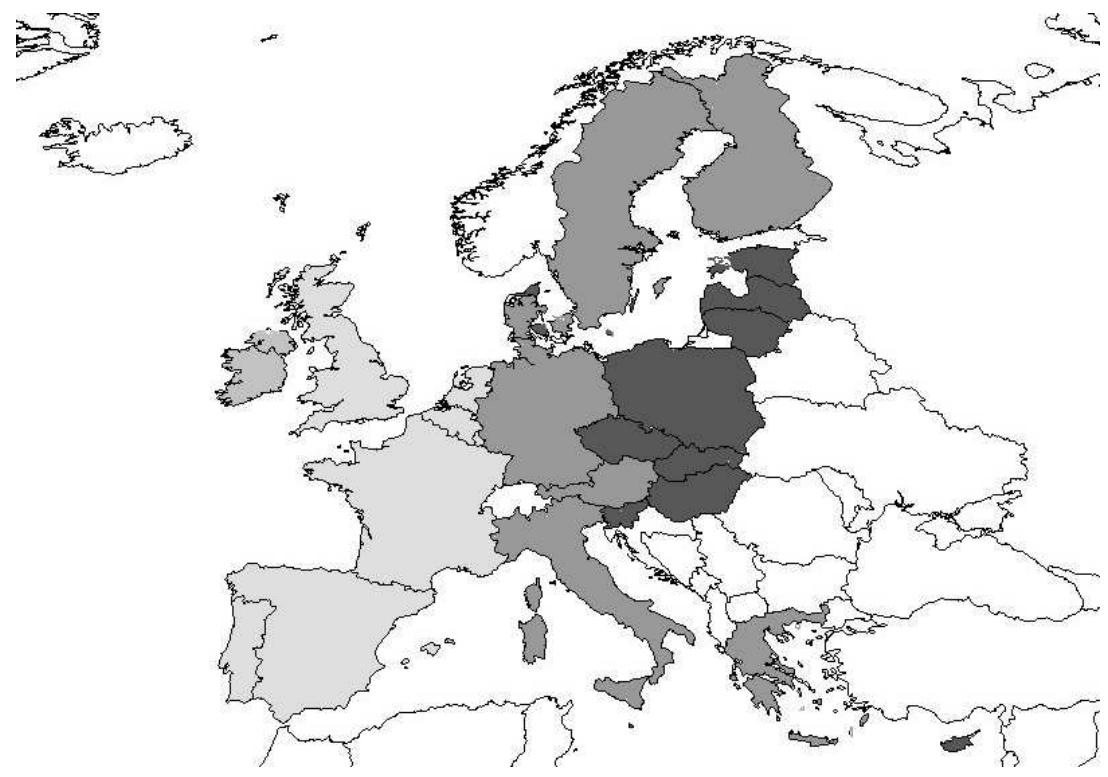

- new member states (Estonia, Latvia, Lithuania, Poland, Hungary, Czech Republic, Slovakia, and Slovenia)

= neighbors of NMS (Sweden, Denmark, Germany, Austria, Italy and Greece)

$\square=$ Ireland

$\square$ = non-neighbors of NMS (The Netherlands, Bel gium, France, UK, Spain and Portugal)

Figure A: Map of EU25 


\section{B. Model derivations}

\section{B.1. Profit maximization}

The inverse demand functions in the model are derived from:

$Q=M-b P$ where for simplicity is assumed that $\mathrm{b}=1 . \Rightarrow P_{A}=M-Q_{A}$ and $P_{B}=M-Q_{B}$.

Using these inverse demand functions, the after-tax profits in country A and B are respectively

$$
\begin{aligned}
& \pi_{A}=\left[\left(M-Q_{A}\right) Q_{A}+\left(m-Q_{A B}\right) Q_{A B}-c x Q_{A B}\right]\left(1-t_{A}\right) \\
& \pi_{B}=\left[\left(m-Q_{B}\right) Q_{B}+\left(M-Q_{B A}\right) Q_{B A}-c x^{2} Q_{B A}\right]\left(1-t_{B}\right)
\end{aligned}
$$

Maximizing the after-tax profits leads to the equilibrium output. The maximization is as follows

For A:

$$
\begin{aligned}
\frac{\partial \pi_{A}}{\partial Q_{A}} & =\left(1-t_{A}\right)\left(M-Q_{A}-Q_{A}\right)=0 \\
\Rightarrow Q_{A}^{*} & =\frac{M}{2} \\
\text { and } & \\
\frac{\delta \pi_{A}}{\delta Q_{A B}} & =\left(1-t_{A}\right)\left(\left(m-Q_{A B}\right)-Q_{A B}-c x\right)=0 \\
\Rightarrow Q_{A B}^{*} & =\frac{m-c x}{2}
\end{aligned}
$$


For B:

$$
\begin{aligned}
\frac{\partial \pi_{B}}{\partial Q_{B}} & =\left(1-t_{B}\right)\left(m-Q_{B}-Q_{B}\right)=0 \\
\Rightarrow Q_{B}^{*} & =\frac{m}{2} \\
\text { and } & \\
\frac{\partial \pi_{B}}{\partial Q_{B A}} & =\left(1-t_{B}\right)\left(m-Q_{B A}-Q_{B A}-c x\right)=0 \\
\Rightarrow Q_{B A} & =\frac{M-c x}{2}
\end{aligned}
$$

\section{B.2. Consumer surplus}

Calculate consumer surplus in country A when the MNE is located in A $\left(\mathrm{CS}_{1}\right)$ and when the MNE is located in country $\mathrm{B}\left(\mathrm{CS}_{2}\right)$ :

$$
\begin{aligned}
C S_{1} & =\int_{0}^{Q_{A}^{*}}\left(P_{A} d Q_{A}\right)-P_{A} Q_{A}^{*}=\frac{Q_{A}^{2}}{2}=\frac{M^{2}}{8} \\
C S_{2} & =\int_{0}^{Q_{B A}^{*}}\left(P_{B} d Q_{B A}\right)-P_{B} Q_{B A}^{*}-c x Q_{B A}=\frac{Q_{B A}^{2}-2 c x Q_{B A}}{2} \\
& =\frac{M^{2}-6 c x M+5 c^{2} x^{2}}{8}
\end{aligned}
$$

Proof: $\frac{\delta t_{A}^{*}}{\delta M}>0$

$$
\begin{aligned}
\frac{\partial t_{A}^{*}}{\partial M} & =\frac{4 c x\left(2 M^{2}+2(m-c x)^{2}-4 M\left(4 c x M+5 c^{2} x^{2}-10 c x m\right)\right.}{4\left(M^{2}+(m-c x)^{2}\right)^{2}} \\
& =\frac{c x\left(-2 M^{2}+2(m-c x)^{2}-5 c x M+10 m M\right)}{\left(M^{2}+(m-c x)^{2}\right)^{2}}>0
\end{aligned}
$$

\section{B.3. Comparative statics}

Here we show that the larger market in equilibrium sets a higher tax (lower subsidy):

$$
\begin{array}{r}
t_{A}^{*}>t_{B}^{*} \\
\frac{4 c x M+5 c^{2} x^{2}-10 c x m}{2\left(M^{2}+(m-c x)^{2}\right)}>\frac{4 c x m+5 c^{2} x^{2}-10 c x M}{2\left(m^{2}+(M-c x)^{2}\right)} \\
\left(M^{2}-m^{2}\right)(7(M-m)-4 c x)+(M-m)\left(2 c^{2} x^{2}-7 m M\right)>0
\end{array}
$$


Here we show that distance to a low tax country matters for the tax premium that a large country can set:

Proof: $\frac{\delta t_{A}^{*}}{\delta x}>0$

$$
\begin{aligned}
\frac{\partial t_{A}^{*}}{\partial x} & =\frac{\left(4 c M+10 c^{2} x-10 c m\right)\left(2 M^{2}+2(m-c x)^{2}+4 c(m-c x)\left(4 c x M+5 c^{2} x^{2}-10 c x m\right)\right.}{4\left(M^{2}+(m-c x)^{2}\right)^{2}} \\
& =\frac{2 c M^{3}+(m-c x)^{2} c(2 M+5 c x-5 m)+c(m-c x)\left(4 c x M+\left(c^{2} x^{2}-10 c x m-5 M^{2}\right)\right.}{\left(M^{2}+(m-c x)^{2}\right)^{2}}
\end{aligned}
$$

\section{Variable definitions}

This appendix gives an overview of the different variables and data sources. 


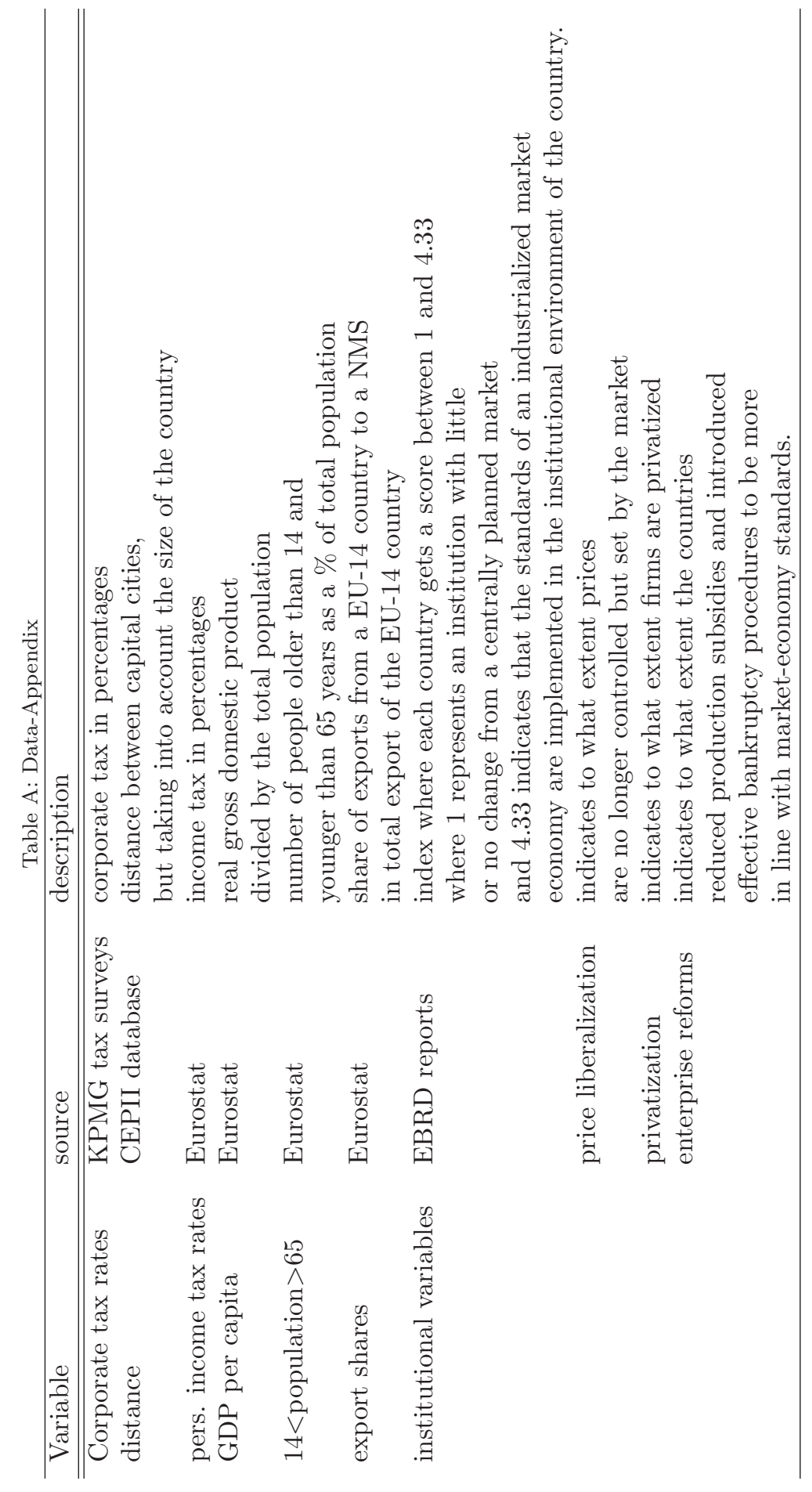




\section{First stage regression results}

The following tables report the first stage results of the regression in column (1) of Table 1 and in column (1) of Table 2.

Table B: First stage regression of benchmark regression in Table 1, column (1)

\begin{tabular}{|c|c|}
\hline & $W_{i j} \operatorname{Tax}_{N M S, t}$ \\
\hline$W_{i j}$ population $>14_{j, t}$ & $\begin{array}{r}0.81^{* *} \\
(0.38)\end{array}$ \\
\hline$W_{i j}$ population $<65_{j, t}$ & $\begin{array}{r}-3.57^{* * *} \\
(0.69)\end{array}$ \\
\hline$W_{i j} g d p$ per capita $a_{j, t}$ & $\begin{array}{r}0.00002 \\
(0.00004)\end{array}$ \\
\hline$W_{i j}$ income $\operatorname{tax}_{j, t-1}$ & $\begin{array}{r}0.02^{*} \\
(0.01)\end{array}$ \\
\hline population $>14 \mathrm{y}_{i, t}$ & $\begin{array}{r}0.15 \\
(0.38)\end{array}$ \\
\hline population $<65_{i, t}$ & $\begin{array}{r}0.25 \\
(0.4)\end{array}$ \\
\hline GDP per capita $i, t$ & $\begin{array}{r}0.00002 \\
(0.0001)\end{array}$ \\
\hline income $\operatorname{tax}_{i, t-1}$ & $\begin{array}{r}0.04 \\
(0.1)\end{array}$ \\
\hline constant & $\begin{array}{r}42.56^{* * *} \\
(14.62) \\
\end{array}$ \\
\hline Obs & 140 \\
\hline R-squared (within) & 0.87 \\
\hline
\end{tabular}


Table C: First stage regression of benchmark regression in Table 2, column (1)

\begin{tabular}{|c|c|}
\hline & $W_{i j} \operatorname{Tax}_{N M S, t}$ \\
\hline $\bar{W}_{i j}$ infrastructure $_{j, t}$ & $\begin{array}{r}2.27 \\
(1.57)\end{array}$ \\
\hline$W_{i j}$ enterprise reform ret $_{j, t}$ & $\begin{array}{r}-18.09 * * * \\
(2.7)\end{array}$ \\
\hline$W_{i j}$ trade $_{\text {liberalization }}, t$ & $\begin{array}{r}-5.96^{* *} \\
(2.79)\end{array}$ \\
\hline population $>14 \mathrm{y}_{i, t}$ & $\begin{array}{r}0.77 \\
(0.49)\end{array}$ \\
\hline population $<65_{i, t}$ & $\begin{array}{r}-0.93^{*} \\
(0.48)\end{array}$ \\
\hline GDP per capita $i, t$ & $\begin{array}{r}-0.0002^{* * *} \\
(0.0001)\end{array}$ \\
\hline income $\operatorname{tax}_{i, t-1}$ & $\begin{array}{r}0.02 \\
(0.12)\end{array}$ \\
\hline constant & $\begin{array}{r}94.83^{* * *} \\
(15.86)\end{array}$ \\
\hline Obs & 154 \\
\hline R-squared (within) & 0.78 \\
\hline
\end{tabular}

\section{References}

Allers, M., Elhorst, P., 2005. Tax mimicking and yardstick competition among local governments in the Netherlands. International Tax and Public Finance 12, 493-513.

Altshuler, R., Goodspeed, T., 2002. Follow the leader? Evidence on European and US tax competition. Rutgers University working papers (200226), 24.

Baldwin, R., Krugman, P., 2004. Agglomeration, integration and tax harmonization. European Economic Review 48 (1), 1-23.

Besley, T., Case, A., 1995. Incumbent behavior: vote seeking, tax setting and yardstick competition. American Economic Review (85), 25-45.

Bloningen, B., Davies, R., Waddell, G., Naughton, H., 2005. Spacey parents: spatial autoregresseive patterins in inbound FDI. NBER working paper series (11466), 30. 
Bloningen, B., Davies, R., Waddell, G., Naughton, H., 2007. FDI in space: spatial autoregresseive relationships in foreign direct investment. European Economic Review 51 (5), $1303-1325$.

Bordignon, M., Cerniglia, F., Revelli, F., 2002. In search for yardstick competition: property tax rates and electoral behavior in Italian cities. Journal of Urban Economics 54 (2), 199217.

Brett, C., Pinkse, J., 2000. The determinants of municipal tax rates in British Columbia. Canadian Journal of Economics 33 (3), 695-714.

Brueckner, J., 2003. Strategic interaction among governments: an overview of empirical studies. International Regional Sience Review 26 (2), 175-188.

Carlsen, F., Langset, B., Rattsø, J., 2005. The relationship between firm mobility and tax level: empirical evidence of fiscal competition between local governments. Journal of Urban Economics 58 (2), 273-288.

Davies, R., Voget, J., 2008. Tax competition in an expanding european union. in mimeo.

Devereux, M., Griffith, R., Klemm, A., 2002. Corporate income tax reforms and international tax competition. Economic Policy 35, 451-495.

Devereux, M., Lockwood, B., Redoano, M., 2008. Do countries compete over corporate tax rates. Journal of Public Economics 92 (5-6), 1210-1235.

Egger, P., Pfafmayer, M., Winner, H., 2005. An unbalanced spatial panel data approach to us state tax competition. Economics Letters 88, 329-335.

Ekholm, K., J.Markusen, Forslid, R., 2007. Export-platform foreign direct investment. Journal of the European Economic Association 5 (4), 776-795.

Haufler, A., Wooton, I., 1999. Country size and tax competition for foreign direct investment. Journal of public economics 71 (1), 121-139.

Head, K., Mayer, T., 2002. Non-europe: the magnitude and causes of market fragmentation in the EU. Weltwirtschaftliches Archiv 136 (2), 285-314. 
Heyndels, B., Vuchelen, J., 1998. Tax mimicking among Belgian municipalities. National Tax Journal 60, 89-101.

Redoano, M., 2003. Fiscal interactions among European countries. Warwick Economic Research papers $(680), 30$.

Ruiz, F., Gerard, M., 2007. Is there evidence of strategic coporate tax interaction among EU countries. Working paper University of Mons, 43.

Vandenbussche, H., Crabbé, K., 2006. De vennootschapsbelasting: de positie van België in het verruimde Europa, "corporate taxes: the position of Belgium in the enlarged Europe". Review of Business and Economics L1, 129 - 151.

Woolridge, J., 2003. Econometric analysis of cross section and panel data. Cambridge, MIT press. 
Département des Sciences Économiques de l'Université catholique de Louvain

Institut de Recherches Économiques et Sociales

Place Montesquieu, 3

1348 Louvain-la-Neuve, Belgique 